\title{
Delayed asphyxia due to inhalation injury
}

\author{
Tony Fracasso • Andreas Schmeling
}

Received: 16 February 2010 /Accepted: 31 March 2010/Published online: 18 May 2010

(C) Springer-Verlag 2010

\begin{abstract}
We report the case of a 53-year-old man who was found dead in his apartment 2 days after a little fire during which he had suffered from second to third degree burns at $2 \%$ of the body surface, also involving the skin around the mouth and the nose. At autopsy, severe acute emphysema and mucopurulent obstructive laryngotracheobronchitis were observed. The histology showed desquamative loss of the respiratory epithelium up to the middle bronchi; the bronchial lumen was filled with clumps of mucopurulent secretions mixed with necrotic epithelial cells. The cause of death was a delayed asphyxia due to inhalation injury.
\end{abstract}

Keywords Asphyxia - Inhalation injury ·

Forensic histopathology

\section{Introduction}

Burn injuries and cases of death related to fire are a classical topic in legal medicine [1], which still evokes interest in the medicolegal scientific community $[2,3]$; in front of a burnt body, an important task is the identification of signs of vitality [4-6]. At this purpose, the most important organ system is the respiratory one $[4,7]$ : here, in fact, the presence of soot particles as well as pathological changes due to thermal and toxic damage are indicative of vital heat

T. Fracasso $\cdot$ A. Schmeling

Institute of Legal Medicine, University Hospital,

Münster, Germany

T. Fracasso $(\square)$

University Center of Legal Medicine,

Rue Michel-Servet 1,

CH-1211 Geneva 4, Switzerland

e-mail: Tony.fracasso@hcuge.ch exposure [4-11]. However, in cases of initially survived burns or inhalation traumas, pathological changes at the respiratory tract can also play important roles in determining delayed death in a minor number of fire victims [12].

We report here a case of delayed asphyxia following inhalation injury.

\section{Case report}

The body of a 53-year-old man was found dead in his apartment by his brother who had received, the evening before, an e-mail in which the victim communicated that, 2 days before, an electric kettle had caused a fire in his apartment. At the time of writing, he complained about hoarseness and sore throat.

At the scene, the consequences of the fire were particularly evident in the kitchen: a burnt electric kettle was lying in the washbowl. Abundant soot was evident at the floor and the walls.

The body was lying on the left side, on the bathroom floor.

At external examination, the body was $169 \mathrm{~cm}$ tall and weighed $68 \mathrm{~kg}$. Second to third degree burn injuries were visible at nose and lips (Fig. 1) as well as hands and feet, involving approximately $2 \%$ of the body surface.

At internal examination, the lungs showed severe acute emphysema and isolated subpleural petechial bleedings. The right lung weighted $870 \mathrm{~g}$, the left one $660 \mathrm{~g}$. No areas of consolidation could be felt. The cut surface was congested and diffusely crepitant. At the larynx, erythema and severe oedema obliterating the piriform sinuses and causing swelling of the epiglottis, aryepiglottic folds and ventricular folds were visible. The lower larynx and the upper trachea were covered by a thick greenish purulent membrane (Fig. 2). These secretions determined the 


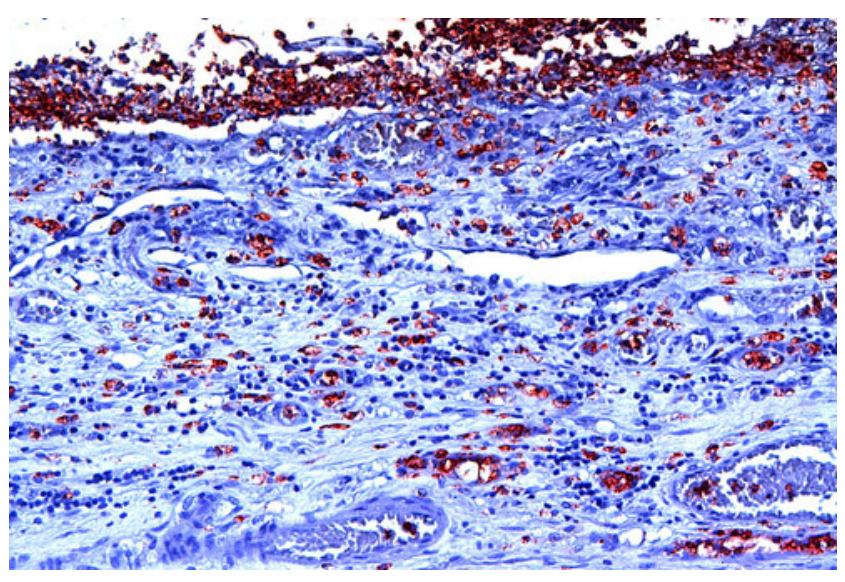

Fig. 1 Epiglottis (posterior aspect). Because of the complete epithelial loss, the intact corrugated basement membrane is covered by mucopurulent material. In the remaining mucosa, a moderate granulocytic infiltration and a severe congestion are visible (immunohistochemical reaction with NP57, $\times 200$ )

apparent total occlusion at the level of the true cords. Numerous little mucosal bleedings were visible, after removal of the firmly adherent membranes. The mucosa of the main bronchi was also reddened and covered by greenish purulent material mixed with carbonaceous particles. Bleedings were not visible. Other pathological finding were severe cerebral oedema and light arteriocoronarosclerosis. Toxicological analysis was negative.

At histology, the epiglottis showed complete loss of the epithelium of the laryngeal side with congestion, swelling and moderate monocyte infiltration of the submucosa. Fibrin, epithelial necrotic material and purulent material covered the congested mucosa. The buccal side of the epiglottis did not show any pathological signs. The trachea also showed loss of the epithelium. The basement mem-

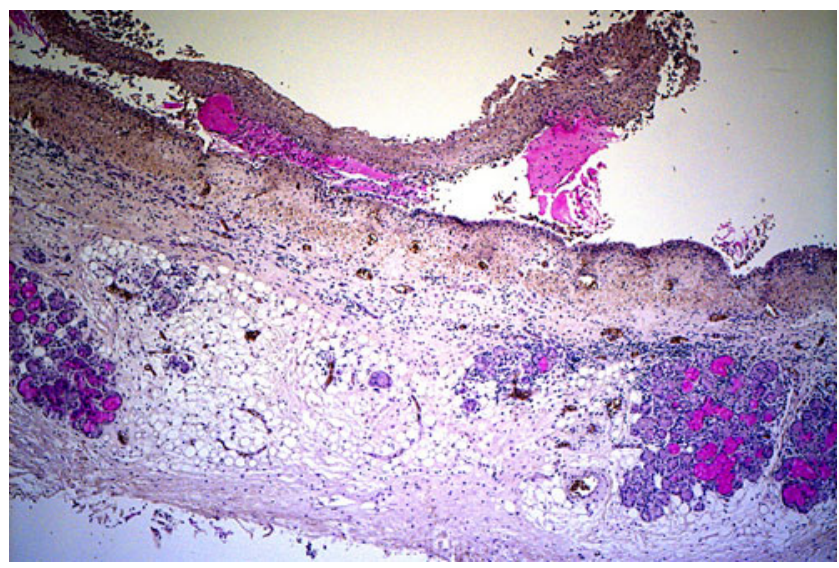

Fig. 2 Trachea. Also at this level, there is complete loss of the epithelium with intact basement membrane. The outer layer of the mucosa shows a severe inflammatory infiltration. In the lamina submucosa, the infiltration is scattered. The PAS staining clearly shows the augmented mucous secretion (PAS, $\times 40$ )

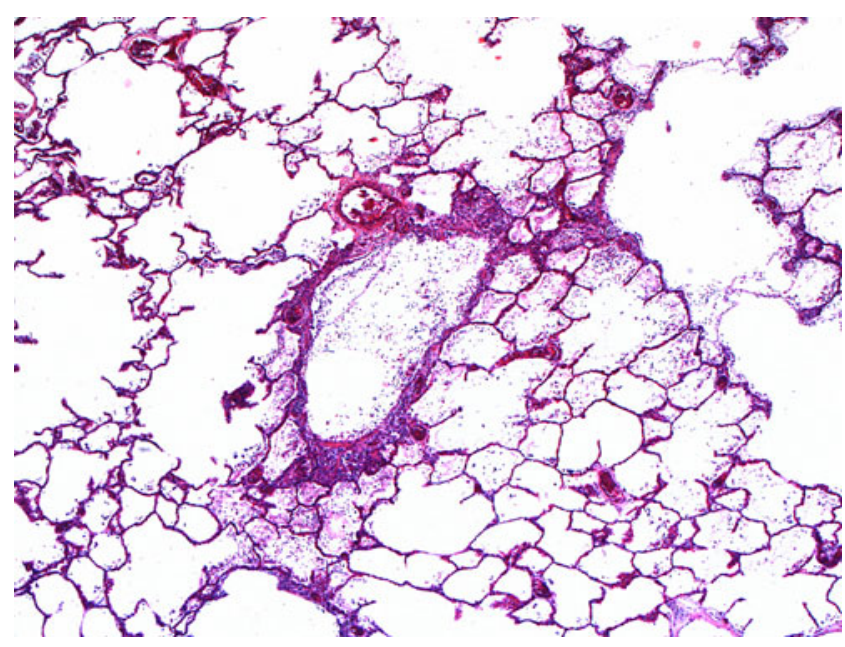

Fig. 3 Middle bronchi. At this level, severe congestion and inflammatory, mainly granulocytic, infiltration of the walls are visible. The peribronchial alveolar spaces are hyperinflated and show erythrocyte extravasation and beginning granulocyte infiltration $(\mathrm{H} \& \mathrm{E}, \times 40)$

brane was intact. The wall was congested. In the tracheal lumen, necrotic epithelium and purulent material were mixed to abundant mucous secretions from hyperactive mucosal glands. The middle bronchi showed detachment of the epithelium with severe congestion and inflammatory, mainly granulocytic, infiltration of the walls. The lumen was often almost completely occupied by clumps of mucopurulent secretions mixed with necrotic epithelial cells. The peribronchial alveolar spaces showed erythrocyte extravasation and beginning granulocyte infiltration, their walls were congested and sticking phenomenon was evident (Figs. 3 and 4). The respiratory bronchioles were often hyperinflated; many alveoli contained oedema fluid in the form of granular precipitate.

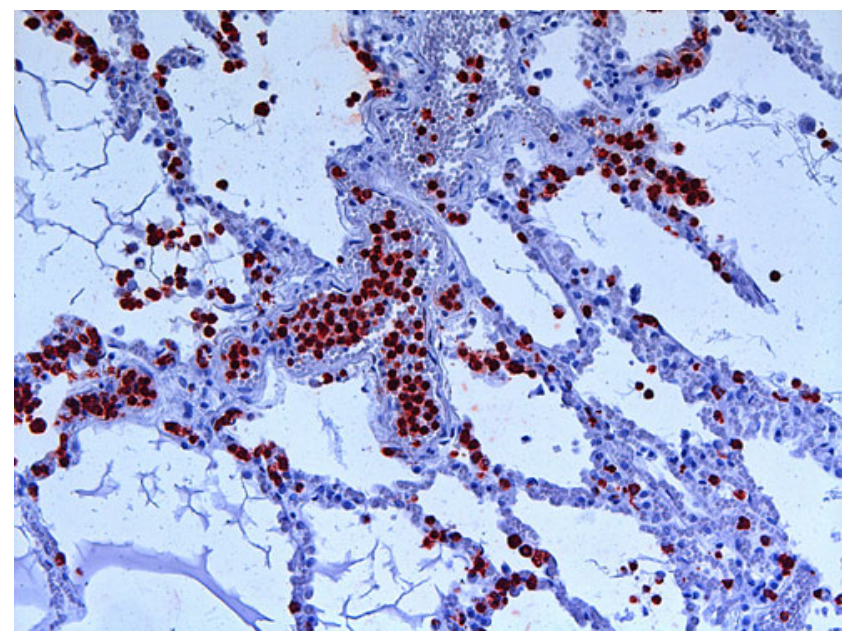

Fig. 4 Lung parenchyma. Sticking phenomenon was particularly evident at proximity of the bronchial tree (immunohistochemical reaction with NP57, ×200) 
On the base of the macro- and microscopic findings, a diagnosis of delayed asphyxia due to inhalation injury was made.

\section{Discussion}

Macro-microscopic changes of the respiratory tract are an important element in the evaluation of vitality in cases of lethal fire [4-11]. At autopsy, swelling and vesicular or patchy detachment of the mucosa of the pharynx or epiglottis with acute congestion of the mucosa of the airways is often observed. At histology, the mucous secretion is increased; a swelling of the vacuoles of the epithelium with pseudo-goblet cells, nucleic elongation and palisade arrangement of the epithelial layer of trachea and bronchi can be observed [7]. All these findings have to be evaluated in the context of the specific case, as similar changes can also be the consequence of post mortem heat exposure or autolysis $[5,6]$.

In initially survived burns, where the question of the vitality is not relevant, the pathological changes of the airways can play a major role in determining the prognosis. In an ovine model, Cox et al. [13] could demonstrate that relevant bronchial obstruction occurs after inhalation trauma, reaches a maximum after $24 \mathrm{~h}$ and is followed by bronchiolar obstruction whose peak is reached after $72 \mathrm{~h}$. The increase in bronchiolar obstruction is partially due to distal migration of bronchial obstructive casts mainly constituted of mucous and cell debris [14]. The bronchial obstruction and the distal migration of potentially contaminated bronchial obstructive material increase the risk of pneumonia [14].

In this case, the man was involved in a minor domestic fire that took place in a little closed room, in the presence of hot smokes. He suffered multiple burn injuries, which covered a limited body surface, with inclusion of the skin around mouth and nose. The occurrence of fire in closed settings, with heat and burns involving the face, are all well-known risk factors for inhalation injury $[15,16]$. The victim underestimated the importance of his injuries and decided not to go to the hospital. The progressive reactive changes at the upper respiratory tract and the diffuse bronchial stenosis determined death due to obstructive asphyxia.

The classical macro-microscopic correlates of asphyxia include acute pulmonary emphysema and congestion, focal hemorrhagic oedema, microembolism, and alveolar macrophages and giant cells [17-19]. In our case, acute pulmonary emphysema was evident, whilst the other morphological signs of asphyxia could not be detected in the investigated lung samples. If compared with the findings described in cases of inhalation of hot steam with comparable time between heat exposure and death $[4,5]$, our case shows similar inflammatory changes, however with a more limited extension to the upper respiratory tract; this is due to the higher heat-carrying capacity of steam compared to hot air. The pathological changes we report in this case represent the natural evolution of the classical signs of vitality at the respiratory tract described in the medicolegal literature. In the majority of fire victims who rapidly die, death occurs due to $\mathrm{CO}$ intoxication and/or extensive burns [1]. Delayed deaths after hospitalisation usually occur as a consequence of the burns or because of respiratory failure due to ARDS or pneumonia. The lifethreatening obstruction of the upper airway is a known complication, which usually occurs in the first $48 \mathrm{~h}$ after trauma, with peak oedema and obstruction due to accumulated secretions [20]. Patients at risk are usually intubated. The easy prevention in hospitalised patients at risk explains the unusual occurrence of such cases of death.

This case demonstrates the importance of inhalation injury, not only as sign of vitality but also as a potential cause of death in cases without major burns which do not undergo medical assistance.

\section{References}

1. Prokop O (1976) Die Einwirkung hoher Temperaturen. In: Prokop O, Göhler W (eds) Forensische Medizin, 3. Aufl. Gustav Fischer, Stuttgart, pp 139-151

2. Faller-Marquardt M, Pollak S, Schmidt U (2008) Cigarette burns in forensic medicine. Forensic Sci Int 176:200-208

3. Fracasso T, Pfeiffer H, Pellerin P, Karger B (2009) The morphology of cutaneous burn injuries and the type of heat application. Forensic Sci Int 187:81-86

4. Brinkmann B, Püschel K (1978) Heat injuries to the respiratory system. Virchows Arch A Path Histol 379:299-311

5. Brinkmann B, Kleiber M, Koops E, Püschel K (1979) Vitale Reaktionen bei akutem Verbrühungtod. Z Rechtsmed 83:1-16

6. Bohnert M, Werner CR, Pollak S (2003) Problems associated with the diagnosis of vitality in burned bodies. Forensic Sci Int 135:197-205

7. Bohnert M (2004) Morphological findings in burned bodies. In: Tsokos M (ed) Forensic pathology reviews, vol I. Humana, Totowa, pp 3-27

8. Foerster A (1932) Über Veränderungen der Luftröhrenschleimhaut bei Verbrannten. Dtsch Z ges Gerichtl Med 19:293-301

9. Foerster A (1933) Experimentelle Untersuchungen über Veränderungen an den Atmungsorganen bei plötzlicher Einwirkung höher Temperaturen. Dtsch Z ges Gerichtl Med 20:445-461

10. Foerster A (1934) Mikroskopische Untersuchungen über das Verhalten der Alveolen bei Verbrannten. Dtsch Z ges Gerichtl Med 23:281-288

11. Bohnert M, Schmidt U, Werp J, Simon KH (2007) Ungewöhnliche Befunde bei einem Todesfall durch Fahrzeugbrand. Arch Kriminol 219:14-22

12. Mallory TB, Brickley WJ (1943) Pathology: with special reference to the pulmonary lesions. Ann Surg 117:865-884

13. Cox RA, Burke AS, Soejima K, Murakami K, Katahira J, Traber LD, Herndon DN, Schmalstieg FC, Traber DL, Hawkins HK 
(2003) Airway obstruction in sheep with burn and smoke inhalation injuries. Am J Respir Cell Mol Biol 29:295-302

14. Cox RA, Mlcak RP, Chinkes DL, Jacob S, Enkhbaatar P, Jaso J, Parish LP, Traber DL, Jeschke MJ, Herndon DN, Hawkins HK (2008) Upper airway mucus deposition in lung tissue of burn trauma victims. Shock 29:356-361

15. Haponik EF, Summer WR (1987) Respiratory complications in burned patients: pathogenesis and spectrum of inhalation injury. $\mathbf{J}$ Crit Care 2:49-74

16. Garner MJP, Jenner J, Parkhouse DAF (2005) Prediction of upper airway closure in inhalation injury. Mil Med 170:677-682
17. Brinkmann B, Fechner G, Püschel K (1984) Identification of mechanical asphyxiation in cases of attempted masking of the homicide. Forensic Sci Int 26:235-245

18. Schmeling A, Fracasso T, Pragst F, Tsokos M, Wirth I (2009) Unassisted smothering in a pillow. Int J Leg Med 123:517519

19. Strunk T, Hamacher D, Schulz R, Brinkmann B (2010) Reaction patterns of pulmonary macrophages in protracted asphyxiation. Int J Leg Med. doi:10.1007/s00414-009-0410-3

20. Peters WJ (1981) Inhalation injury caused by the products of combustion. CMA Journal 125:249-252 